九州大学学術情報リポジトリ

Kyushu University Institutional Repository

\title{
Particle-size Distribution and Free Iron 0xides of Alluvial Soils from Different Agro- ecological Regions in Vietnam
}

Nguyen Quang Hai

Laboratory of Soil Science, Division of Soil Science and Plant Production, Department of Plant Resources, Graduate School of Bioresource and Bioenvironmental Sciences, Kyushu University

Egashira, Kazuhiko

https://doi.org/10.5109/4641

出版情報: 九州大学大学院農学研究院紀要. 50 (1)，pp.243-254，2005-02-01. Faculty of Agriculture, Kyushu University

バージョン：

権利関係 : 
J. Fac. Agr., Kyushu Univ., 50 (1), 243-254 (2005)

\title{
Particle-size Distribution and Free Iron Oxides of Alluvial Soils from Different Agro-ecological Regions in Vietnam
}

\author{
NGUYEN Quang Hai ${ }^{1}$ and Kazuhiko EGASHIRA* \\ Laboratory of Soil Science, Division of Soil Science and Plant Production, \\ Department of Plant Resources, Faculty of Agriculture, \\ Kyushu University, Fukuoka 812-8581, Japan \\ (Received October 25, 2004 and accepted November 11, 2004)
}

\begin{abstract}
Sixteen profiles of alluvial soils of Vietnam were collected from different agro-ecological regions throughout the country and analyzed for particle-size distribution and free iron oxides. The results showed that alluvial soils from different agro-ecological regions/river systems had different particle-size distribution and free iron oxides contents due to differences in sediment sources. The vertical distribution of the clay content in a profile was found to be controlled by soil forming processes and/or land management and was divided into 5 patterns. Similarly, the vertical distribution of free iron oxides content in a profile reflected soil forming process and land management; and in most profiles it showed a significant linear relationship with the clay content. Many samples of alluvial soils showed the clay loss and the lower content of free iron oxides in upper horizons. This feature was the same as that observed in grey degraded soils but at the lower level. It seems that some alluvial soils in Vietnam have been degraded.
\end{abstract}

\section{INTRODUCTION}

Vietnam is situated within $8^{\circ} 10^{\prime}$ to $23^{\circ} 24^{\prime} \mathrm{N}$ latitude and $102^{\circ} 09^{\prime}$ to $109^{\circ} 30^{\prime} \mathrm{E}$ longitude ranges in the Indochina Peninsula. This location makes it own tropical to subtropical monsoon with two distinct seasons: rainy (April to October) and dry (November to March) seasons. Although it is narrow in width, Vietnam has a very complicated topography and diversified geology. Based on topography, geology, climate, and vegetation, the whole country is divided into 9 agro-ecological regions (Fig. 1). Alluvial soils in Vietnam are mainly situated in the Red River Delta and the West of the South regions. Small areas of alluvial soils are distributed along the seashore, belonging to the North of Central, the Coastal Area of Southern Central and the East of the South regions (NISF and DSTPQ, 2002). Because of originating from differences of sediment sources in different agro-ecological regions, characteristics of alluvial soils might be various, of which are particle-size distribution and free iron oxides content.

It has been well-known that soil particle-size distribution is one of the most important physical attributes and mostly used in soil classification as well as for estimating various related soil properties (Hillel, 1980). Separates consisting of larger particles (sand and gravel) form the skeleton of the soil and determine many of its mechanical properties. The finest separate, consisting of clay particles, has a large surface area and

1 Laboratory of Soil Science, Division of Soil Science and Plant Production, Department of Plant Resources, Graduate School of Bioresource and Bioenvironmental Sciences, Kyushu University

* Corresponding author (E-mail: kegashi@agr.kyushu-u.ac.jp) 


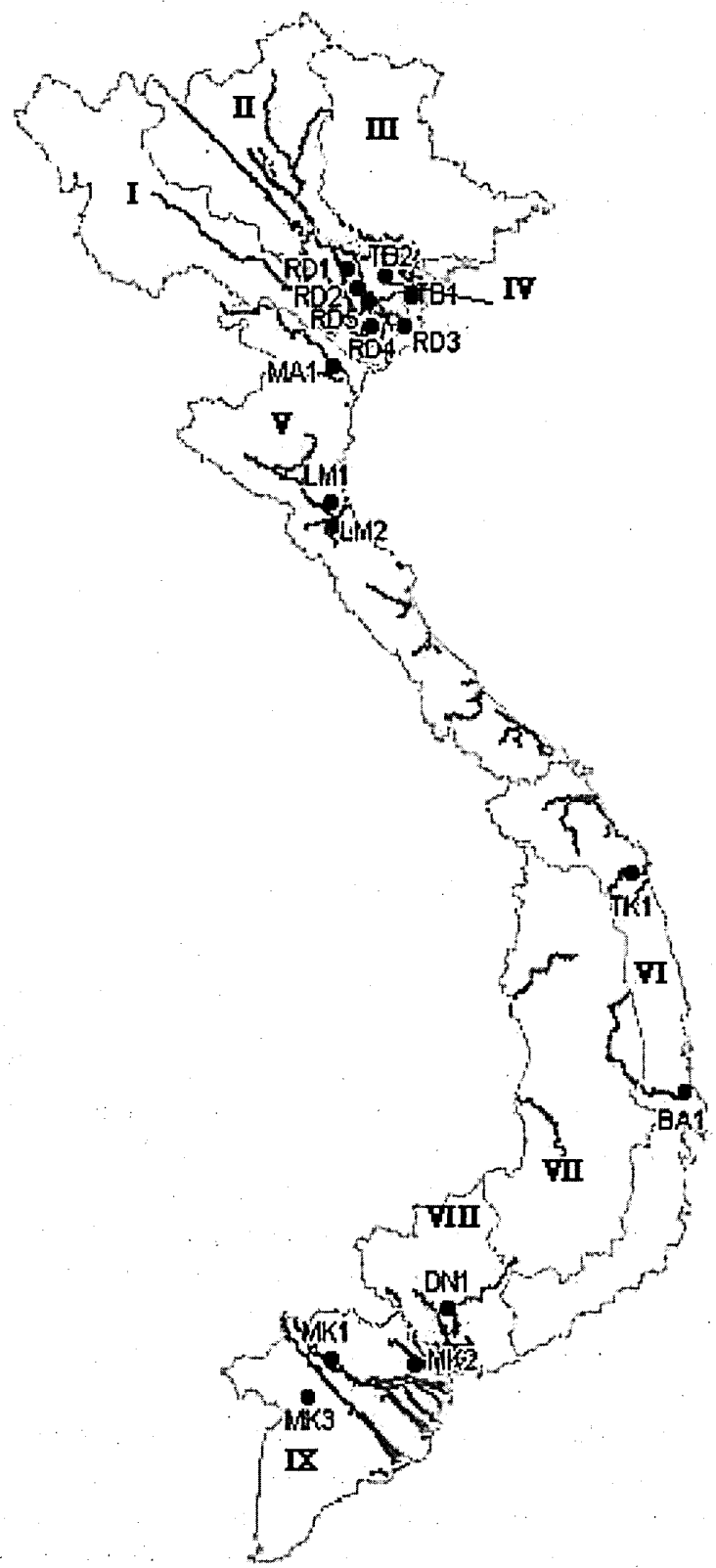

Fig. 1. Soil sampling sites on the map of agro-ecological regions of Vietnam.

I. Northwest region; II. Northern region; III. Northeast region; IV. Red River Delta region; V. North of Central region; VI. Coastal Area of Southern Central region; VII. High Plateau Tay Nguyen region; VIII. East of the South region; IX. West of the South region. 
determines most of the chemical and physico-chemical properties of the soils (Yong and Warkentin, 1975). Besides, the amount and distribution of extractable iron oxides in soil profiles serve as indicators of the degree of soil development and of the direction of pedogenic processes (Asamoa, 1973).

The purposes of the present study are: (1) to examine the particle-size distribution and free iron oxides content of alluvial soils from different agro-ecological regions in Vietnam and to clarify the factors controlling variation of them; and (2) to test the relationship between free iron oxides content and clay particle content, and their reference to soil development, because free iron oxides are often closely associated with clay-sized particles (Asamoa, 1973).

\section{MATERIALS AND METHODS}

\section{Soils}

Sampling sites of 16 profiles of alluvial soils are shown on the map of agro-ecological regions of Vietnam in Fig. 1, and general information on soil profiles is shown in Table 1. No sample was collected from the Northwest, Northern, Northeast and High Plateau Tay Nguyen regions, because of limited distribution of paddy soils in these regions. All of soil samples in the present study were taken in the two projects: (1) Surveying and Evaluating Soil Quality to Establish Soil Reference, Database and Information; and (2) Study in Establishing the Data Guidelines on Environmental Quality of Vietnam Fluvisols. Seven out of 16 profiles belong to the Red River Delta region, of which 5 are from the Red River system (RD1 through RD5) and 2 from the Thaibinh River system (TB1 and TB2). Profiles MA1 (Ma River system) and LM1 and LM2 (Lam River system) belong to the North of Central region. Profiles TK1 (Trakhuc River system) and BA1 (Ba River system) are distributed in the Coastal Area of Southern Central region. Profile DN1

Table 1. General information on alluvial soils in Vietnam.

\begin{tabular}{cllll}
\hline Profile & \multicolumn{1}{c}{$\begin{array}{c}\text { Location } \\
\text { (district, province) }\end{array}$} & $\begin{array}{c}\text { Agro-ecological } \\
\text { region }\end{array}$ & River system & $\begin{array}{c}\text { Soil classification } \\
\text { (FAO/UNESCO) }\end{array}$ \\
\hline RD1 & Thuong Tin, Ha Tay & Red River Delta & Red River & Eutric Fluvisols \\
RD2 & Khoai Chau, Hung Yen & & Red River & Eutric Fluvisols \\
RD3 & Kien Xuong, Thai Binh & & Red River & Dystric Fluvisols \\
RD4 & Vu Ban, Nam Dinh & & Red River & Gleyic Fluvisols \\
RD5 & Duy Tien, Ha Nam & & Red River & Gleyic Fluvisols \\
TB1 & Quynh Phu, Thai Binh & & Thaibinh River & Dystric Fluvisols \\
TB2 & Cam Binh, Hai Duong & & Thaibinh River & Cambic Fluvisols \\
\hline MA1 & Yen Dinh, Thanh Hoa & North of Central & Ma River & Dystric Fluvisols \\
LM1 & Hung Nguyen, Nghe An & & Lam River & Dystric Fluvisols \\
LM2 & Duc Tho, Ha Tinh & & Lam River & Cambic Fluvisols \\
\hline TK1 & Tu Nghia, Quang Ngai & Coastal Area of & Trakhuc River & Cambic Fluvisols \\
BA1 & Tuy Hoa, Phu Yen & Southern Central & Ba River & Dystric Fluvisols \\
\hline DN1 & Vinh Cuu, Dong Nai & East of the South & Dongnai River & Dystric Fluvisols \\
\hline MK1 & Cao Lanh, Dong Thap & West of the South & Mekong River & Eutric Fluvisols \\
MK2 & Chau Thanh, Long An & & Mekong River & Dystric Fluvisols \\
MK3 & Thot Not, Can Tho & & Mekong River & Gleyic Fluvisols \\
\hline
\end{tabular}


from the Dongnai River system is in the East of the South region and profiles MK1 through MK3 from the Mekong River system are in the West of the South region.

Soil samples were taken vertically with profile depth based on the genetic horizons, air-dried and gently ground to pass through a 2-mm sieve in Vietnam, and subjected to analyses for particle-size distribution and free iron oxides in Kyushu University, Japan.

\section{Procedures for analyses}

Particle-size distribution was measured by the method as described in the paper of Do et al. (2002). Ten gram of air-dried soil was weighed into a 500-mL tall beaker and $100 \mathrm{~mL}$ of $7 \% \mathrm{H}_{2} \mathrm{O}_{2}$ was added. The beaker was then covered with a watch-glass and stood for about 10 minutes until frothing ceased. Organic matter was removed by heating at $90^{\circ} \mathrm{C}$ for about 2 hours. After cooling, the content of the beaker was transferred to a $250-\mathrm{mL}$ centrifuge tube followed by centrifugation and decantation, and washed with water 3 times to remove excess $\mathrm{H}_{2} \mathrm{O}_{2}$. In each washing, $5 \mathrm{~mL}$ of $3 \mathrm{M} \mathrm{NaCl}$ was added to prevent deflocculation of clay particles. The soil was then transferred to the tall beaker again and water was added to a volume of $400 \mathrm{~mL}$. The soil suspension was adjusted to $\mathrm{pH} 10$ by addition of small amounts of $1 \mathrm{M} \mathrm{NaOH}$ and dispersed by ultrasonic vibration for 15 minutes. The suspension was transferred to a 1-L sedimentation cylinder and made to volume with water. The cylinder was covered with a rubber stopper, shaken by hand for 1 minute and then placed on a firm table. After standing for an appropriate time, dependent on the suspension temperature, the $<2 \mu \mathrm{m}$ clay fraction was siphoned out into a $2-\mathrm{L}$ plastic beaker. About $30 \mathrm{~mL}$ of $3 \mathrm{M} \mathrm{NaCl}$ was added, for each $1 \mathrm{~L}$, to flocculate clay particles. By repetition of the treatment of sonification-sedimentation-siphoning with intermittent $\mathrm{pH}$ adjustments, the whole $<2 \mu \mathrm{m}$ clay fraction was separated. The whole $2-20 \mu \mathrm{m}$ silt fraction was separated by repeated sedimentation and siphoning. The $20-200$ and $200-2,000 \mu \mathrm{m}$ sand fractions were separated by wet-sieving. After oven-drying at $105^{\circ} \mathrm{C}$, each fraction was weighed for calculation of the particle-size distribution. In the clay fraction, a portion of the clay suspension was taken in a $10-\mathrm{mL}$ centrifuge tube followed by removal of excess salt before oven-drying at $105^{\circ} \mathrm{C}$, and the clay concentration was multiplied by the volume of the suspension to calculate weight of the whole clay fraction.

The method as described in the paper of Egashira et al. (2002) was followed to determine free iron oxides. Zero-point-five (0.5) g of the finely-ground air-dried soil was weighed into a centrifuge bottle. Zero-point-five (0.5) g of sodium hydrosulfite and $25 \mathrm{~mL}$ of the citrate solution ( $220 \mathrm{~g}$ of $\mathrm{Na}_{3} \mathrm{C}_{6} \mathrm{H}_{5} \mathrm{O}_{7} \cdot 2 \mathrm{H}_{2} \mathrm{O}$ was dissolved into $1 \mathrm{~L}$ of deionized water) were added to the bottle, followed by shaking mechanically at room temperature for extraction of free iron oxides. After centrifugation at 5,000 rpm for 10 minutes, the supernatant was transferred to a measuring flask. The extraction procedure was repeated once or twice more for the samples keeping the red to yellow color. Twenty $\mathrm{mL}$ of deionized water was added to the sample after extraction, and the suspension was shaken by hand several times. The supernatant was collected to the measuring flask after centrifugation. This washing procedure was repeated twice more. The extracted solution was diluted ten times with deionized water after filling-up the flask and was stood for two days in a loosely-capped plastic bottle to decompose reducing compounds. The concentration of iron in the solution was determined by an atomic absorption spectrophotometer. 


\section{RESULTS AND DISCUSSION}

Analyzed data of alluvial soils are shown in Table 2. Data of the particle-size distribution were obtained from only one measurement, and the values of the free iron oxides content are an average of the duplicate measurements.

\section{Particle-size distribution}

The particle-size distribution of all samples is given in Table 2, and that averaged for samples of the respective agro-ecological regions is shown in Table 3. For all samples, the coarse sand contents were normally lower than $1 \%$, while variability in the clay, silt and fine sand contents was very large: the clay content varied from 15.8 to $62.6 \%$, the silt content from 13.6 to $57.3 \%$, and the fine sand content from 1.7 to $66.6 \%$. As indicated in Table 3, the particle-size distribution and soil texture of alluvial soils had a close relationship with the agro-ecological regions. For samples of the Red River Delta region, the average clay, silt and fine sand contents were $36.7,38.4$ and $24.4 \%$, respectively. In this agro-ecological region, the soil texture considerably varied with the soil units. As a result, Eutric Fluvisols (profiles RD1 and RD2) had the texture coarser than light clay and silty clay; most samples of Dystric Fluvisols (profiles RD3 and TB1) had the texture finer than light clay and silty clay; while most samples of Gleyic Fluvisols (profiles RD4 and RD5) and Cambic Fluvisols (profile TB2) had the texture of heavy clay. For samples of the North of Central region, soil texture was light clay, silty clay or heavy clay with the high clay (47.0\%) and silt (41.8\%) contents and the low fine sand content (10.7\%). Most samples of the Coastal Area of Southern Central region had the texture of light clay with relatively equal ratios of the clay, silt and fine sand contents $(35.3,27.6$ and $33.3 \%$, respectively). Alluvial soils of the East of the South and the West of the South regions were characterized by the heavy clay texture with the very high clay content (more than $50 \%)$. The silt content of the latter (42.7\%) was higher than that of the former $(26.1 \%)$, while the fine sand content was much lower for the latter $(5.0 \%)$ than for the former (20.4\%). The differences in the particle-size distribution and soil texture among the agro-ecological regions can be attributed to the differences in the sediment sources, while those within an agro-ecological region, for example the Red River Delta region, can be attributed to the differences in the land form and soil forming process.

The silt content showed the very large variability for all samples but was remarkably constant within a profile. Therefore, the soil texture of each profile mainly depended on the relative clay and fine sand contents. The statistical analysis indicated that the clay and fine sand contents of samples had a significant and negative relationship for all profiles, with a correlation coefficient of $-0.837^{* * *}$ (Fig. 2). Because of this relationship, we can use the vertical distribution of either clay or fine sand content as an indicator to examine the change of the soil texture with depth in a profile. In the present study, the clay content was found as a suitable indicator.

Based on the analyzed data, the vertical distribution of the clay content in a profile was grouped into 5 patterns and illustrated in Fig. 3. In the present study of alluvial soils of Vietnam, the vertical distribution pattern of the clay content in a profile was found to be controlled by soil formation process, profile location and land management rather than by differences in the agro-ecological region. The pattern (a) indicates the constancy of 
Table 2. Particle-size distribution and free iron oxides contents of alluvial soils in Vietnam.

\begin{tabular}{|c|c|c|c|c|c|c|c|}
\hline \multirow[b]{2}{*}{ Profile } & \multirow[b]{2}{*}{$\begin{array}{l}\text { Depth } \\
\text { (cm) }\end{array}$} & \multicolumn{4}{|c|}{ Particle-size distribution (\%) } & \multirow{2}{*}{$\begin{array}{c}\text { Soil } \\
\text { texture") } \\
\text { (IUSS) }\end{array}$} & \multirow{2}{*}{$\begin{array}{c}\text { Free iron } \\
\text { oxides } \\
(\mathrm{g} / \mathrm{kg})\end{array}$} \\
\hline & & $\begin{array}{c}\text { Clay } \\
(<2 \mu \mathrm{m})\end{array}$ & $\begin{array}{c}\text { Silt } \\
(2-20 \mu \mathrm{m})\end{array}$ & $\begin{array}{c}\text { Fine sand } \\
(20-200 \mu \mathrm{m})\end{array}$ & $\begin{array}{c}\text { Coarse sand } \\
(200-2,000 \mu \mathrm{m})\end{array}$ & & \\
\hline RD1 & $\begin{array}{c}20-40 \\
56-76 \\
135-147 \\
\end{array}$ & $\begin{array}{l}24.7 \\
18.3 \\
24.0 \\
\end{array}$ & $\begin{array}{l}38.8 \\
29.2 \\
39.6 \\
\end{array}$ & $\begin{array}{l}36.4 \\
52.4 \\
36.3 \\
\end{array}$ & $\begin{array}{l}0.1 \\
0.1 \\
0.1\end{array}$ & $\begin{array}{l}\mathrm{CL} \\
\mathrm{CL} \\
\mathrm{CL}\end{array}$ & $\begin{array}{l}22.7 \\
15.6 \\
19.0 \\
\end{array}$ \\
\hline RD2 & $\begin{array}{c}0-15 \\
15-25 \\
25-40 \\
40-70 \\
70-85 \\
85-95 \\
95-110 \\
\end{array}$ & $\begin{array}{l}34.7 \\
32.2 \\
21.8 \\
34.4 \\
25.5 \\
40.3 \\
15.8\end{array}$ & $\begin{array}{l}51.5 \\
46.5 \\
36.7 \\
54.1 \\
34.8 \\
51.7 \\
20.8\end{array}$ & $\begin{array}{l}13.6 \\
200.5 \\
41.3 \\
11.4 \\
39.6 \\
7.8 \\
63.2\end{array}$ & $\begin{array}{l}0.2 \\
0.8 \\
0.2 \\
0.1 \\
0.1 \\
0.1 \\
0.1\end{array}$ & $\begin{array}{l}\mathrm{SiC} \\
\mathrm{SiC} \\
\mathrm{CL} \\
\mathrm{SiC} \\
\mathrm{LiC} \\
\mathrm{SiC} \\
\mathrm{CL}\end{array}$ & $\begin{array}{l}21.6 \\
23.6 \\
18.3 \\
25.4 \\
24.3 \\
31.6 \\
17.2\end{array}$ \\
\hline RD3 & $\begin{array}{c}0-15 \\
15-40 \\
40-60 \\
60-85 \\
85-120 \\
\end{array}$ & $\begin{array}{l}42.5 \\
44.5 \\
39.3 \\
38.1 \\
48.7 \\
\end{array}$ & $\begin{array}{l}49.1 \\
50.3 \\
53.5 \\
52.0 \\
46.6 \\
\end{array}$ & $\begin{array}{l}8.2 \\
5.1 \\
7.2 \\
9.8 \\
4.5 \\
\end{array}$ & $\begin{array}{l}0.2 \\
0.1 \\
0.1 \\
0.1 \\
0.1\end{array}$ & $\begin{array}{l}\text { SiC } \\
\text { SiC } \\
\text { SiC } \\
\text { SiC } \\
\mathrm{HC}\end{array}$ & $\begin{array}{l}23.9 \\
32.1 \\
29.7 \\
16.9 \\
38.4 \\
\end{array}$ \\
\hline RD4 & $\begin{array}{c}0-20 \\
30-50 \\
65-80 \\
90-110 \\
\end{array}$ & $\begin{array}{l}46.1 \\
46.2 \\
46.5 \\
42.3 \\
\end{array}$ & $\begin{array}{l}43.4 \\
43.2 \\
43.1 \\
43.8 \\
\end{array}$ & $\begin{array}{l}10.4 \\
10.4 \\
10.3 \\
13.8 \\
\end{array}$ & $\begin{array}{l}0.1 \\
0.1 \\
0.1 \\
0.1\end{array}$ & $\begin{array}{l}\mathrm{HC} \\
\mathrm{HC} \\
\mathrm{HC} \\
\mathrm{LiC}\end{array}$ & $\begin{array}{l}36.0 \\
36.8 \\
35.4 \\
41.8 \\
\end{array}$ \\
\hline RD5 & $\begin{array}{c}0-20 \\
20-35 \\
35-60 \\
60-90 \\
90-120\end{array}$ & $\begin{array}{l}30.0 \\
50.2 \\
44.9 \\
52.9 \\
56.7\end{array}$ & $\begin{array}{l}19.3 \\
33.1 \\
29.3 \\
29.1 \\
28.1\end{array}$ & $\begin{array}{l}47.2 \\
16.3 \\
25.3 \\
17.4 \\
14.6\end{array}$ & $\begin{array}{l}3.5 \\
0.3 \\
0.5 \\
0.5 \\
0.6\end{array}$ & $\begin{array}{l}\mathrm{SC} \\
\mathrm{HC} \\
\mathrm{LiC} \\
\mathrm{HC} \\
\mathrm{HC}\end{array}$ & $\begin{array}{l}15.2 \\
23.4 \\
21.9 \\
15.2 \\
19.5\end{array}$ \\
\hline TB1 & $\begin{array}{c}0-20 \\
20-40 \\
40-85 \\
85-110 \\
110-130\end{array}$ & $\begin{array}{l}32.9 \\
38.8 \\
21.8 \\
19.3 \\
16.8\end{array}$ & $\begin{array}{l}36.4 \\
37.1 \\
16.3 \\
23.9 \\
13.6\end{array}$ & $\begin{array}{l}30.4 \\
23.9 \\
61.2 \\
55.0 \\
66.6\end{array}$ & $\begin{array}{l}0.3 \\
0.2 \\
0.7 \\
1.9 \\
3.0\end{array}$ & $\begin{array}{l}\mathrm{LiC} \\
\mathrm{LiCl} \\
\mathrm{SCL} \\
\mathrm{CL}\end{array}$ & $\begin{array}{l}27.9 \\
77.8 \\
43.7 \\
5.3 \\
13.0\end{array}$ \\
\hline TB2 & $\begin{array}{c}0-15 \\
15-23 \\
23-58 \\
58-100\end{array}$ & $\begin{array}{l}46.5 \\
45.3 \\
46.5 \\
43.1\end{array}$ & $\begin{array}{l}40.2 \\
39.8 \\
44.7 \\
46.4\end{array}$ & $\begin{array}{l}13.1 \\
14.5 \\
8.5 \\
10.3\end{array}$ & $\begin{array}{l}0.2 \\
0.4 \\
0.4 \\
0.2\end{array}$ & $\begin{array}{l}\mathrm{HC} \\
\mathrm{HC} \\
\mathrm{HC} \\
\mathrm{SiC}\end{array}$ & $\begin{array}{l}30.7 \\
29.0 \\
37.6 \\
12.8\end{array}$ \\
\hline MAl & $\begin{array}{c}0-10 \\
10-30 \\
30-70 \\
70-100 \\
100-130\end{array}$ & $\begin{array}{l}38.2 \\
52.7 \\
51.0 \\
55.4 \\
62.6\end{array}$ & $\begin{array}{l}34.6 \\
39.7 \\
43.8 \\
41.1 \\
25.0\end{array}$ & $\begin{array}{r}25.7 \\
7.3 \\
4.7 \\
3.4 \\
11.7\end{array}$ & $\begin{array}{l}1.4 \\
0.3 \\
0.5 \\
0.1 \\
0.7\end{array}$ & $\begin{array}{l}\mathrm{LiC} \\
\mathrm{HC} \\
\mathrm{HC} \\
\mathrm{HC} \\
\mathrm{HC}\end{array}$ & $\begin{array}{l}31.3 \\
55.3 \\
52.2 \\
52.6 \\
55.7\end{array}$ \\
\hline LM1 & $\begin{array}{c}0-28 \\
28-50 \\
50-80 \\
80-105 \\
\end{array}$ & $\begin{array}{l}33.2 \\
43.7 \\
43.3 \\
44.6 \\
\end{array}$ & $\begin{array}{l}36.3 \\
37.8 \\
49.8 \\
45.6 \\
\end{array}$ & $\begin{array}{r}29.3 \\
18.4 \\
6.7 \\
9.4\end{array}$ & $\begin{array}{l}1.2 \\
0.1 \\
0.2 \\
0.4\end{array}$ & $\begin{array}{l}\text { LiC } \\
\mathrm{LiC} \\
\mathrm{SiC} \\
\mathrm{SiC}\end{array}$ & $\begin{array}{l}25.1 \\
37.9 \\
42.2 \\
42.0\end{array}$ \\
\hline LM2 & $\begin{array}{r}0-12 \\
12-25 \\
25-45 \\
45-85 \\
\end{array}$ & $\begin{array}{l}36.7 \\
50.6 \\
49.8 \\
48.9 \\
\end{array}$ & $\begin{array}{l}54.4 \\
44.9 \\
45.3 \\
45.3 \\
\end{array}$ & $\begin{array}{l}8.4 \\
3.9 \\
4.8 \\
5.5\end{array}$ & $\begin{array}{l}0.5 \\
0.5 \\
0.1 \\
0.3\end{array}$ & $\begin{array}{l}\mathrm{SiC} \\
\mathrm{HC} \\
\mathrm{HC} \\
\mathrm{HC}\end{array}$ & $\begin{array}{l}19.6 \\
53.1 \\
66.0 \\
82.0\end{array}$ \\
\hline TK1 & $\begin{array}{c}0-15 \\
15-30 \\
30-45 \\
\end{array}$ & $\begin{array}{l}35.4 \\
42.5 \\
50.6\end{array}$ & $\begin{array}{l}36.4 \\
38.7 \\
38.6 \\
\end{array}$ & $\begin{array}{l}24.1 \\
16.2 \\
10.2 \\
\end{array}$ & $\begin{array}{l}4.1 \\
2.5 \\
0.5\end{array}$ & $\begin{array}{l}\mathrm{LiC} \\
\mathrm{LiC} \\
\mathrm{HC}\end{array}$ & $\begin{array}{l}26.1 \\
47.3 \\
47.5 \\
\end{array}$ \\
\hline BA1 & $\begin{array}{c}0-15 \\
15-30 \\
30-50 \\
50-75 \\
75-110 \\
\end{array}$ & $\begin{array}{l}25.7 \\
19.8 \\
31.7 \\
33.3 \\
43.5 \\
\end{array}$ & $\begin{array}{l}22.8 \\
17.4 \\
21.9 \\
23.1 \\
21.6 \\
\end{array}$ & $\begin{array}{l}47.0 \\
56.8 \\
43.3 \\
40.6 \\
28.5 \\
\end{array}$ & $\begin{array}{l}4.5 \\
6.0 \\
3.0 \\
2.9 \\
6.4 \\
\end{array}$ & $\begin{array}{l}\mathrm{LiC} \\
\mathrm{SCL} \\
\mathrm{LiC} \\
\mathrm{LiC} \\
\mathrm{LiC}\end{array}$ & $\begin{array}{l}11.0 \\
13.1 \\
15.3 \\
19.7 \\
24.0 \\
\end{array}$ \\
\hline DN1 & $\begin{array}{c}0-10 \\
10-20 \\
20-70 \\
70-120\end{array}$ & $\begin{array}{l}41.0 \\
46.6 \\
62.0 \\
59.6\end{array}$ & $\begin{array}{l}28.7 \\
29.2 \\
23.8 \\
22.7\end{array}$ & $\begin{array}{l}28.1 \\
21.9 \\
14.1 \\
17.6\end{array}$ & $\begin{array}{l}2.2 \\
2.3 \\
0.1 \\
0.1\end{array}$ & $\begin{array}{l}\mathrm{LiC} \\
\mathrm{HC} \\
\mathrm{HC} \\
\mathrm{HC}\end{array}$ & $\begin{array}{l}74.0 \\
74.0 \\
84.1 \\
75.4\end{array}$ \\
\hline MK1 & $\begin{array}{c}0-10 \\
10-20 \\
20-55 \\
55-95 \\
95-130\end{array}$ & $\begin{array}{l}44.1 \\
53.9 \\
53.3 \\
55.5 \\
59.2\end{array}$ & $\begin{array}{l}47.6 \\
42.6 \\
40.9 \\
41.1 \\
38.9\end{array}$ & $\begin{array}{l}8.2 \\
3.4 \\
5.6 \\
3.1 \\
1.7\end{array}$ & $\begin{array}{l}0.1 \\
0.1 \\
0.1 \\
0.3 \\
0.2\end{array}$ & $\begin{array}{l}\mathrm{SiC} \\
\mathrm{HC} \\
\mathrm{HC} \\
\mathrm{HC} \\
\mathrm{HC}\end{array}$ & $\begin{array}{l}30.2 \\
30.5 \\
46.1 \\
37.2 \\
28.3\end{array}$ \\
\hline MK2 & $\begin{array}{c}0-10 \\
10-30 \\
30-50\end{array}$ & $\begin{array}{l}56.0 \\
52.8 \\
48.8\end{array}$ & $\begin{array}{l}35.5 \\
39.4 \\
43.5\end{array}$ & $\begin{array}{l}6.3 \\
5.4 \\
5.6\end{array}$ & $\begin{array}{l}2.2 \\
2.4 \\
2.1\end{array}$ & $\begin{array}{l}\mathrm{HC} \\
\mathrm{HC} \\
\mathrm{HC}\end{array}$ & $\begin{array}{l}44.9 \\
48.2 \\
38.1\end{array}$ \\
\hline MK3 & $\begin{array}{c}0-15 \\
15-30 \\
30-60 \\
60-90 \\
90-130\end{array}$ & $\begin{array}{l}53.7 \\
59.2 \\
37.6 \\
47.6 \\
47.8\end{array}$ & $\begin{array}{l}38.8 \\
38.5 \\
57.3 \\
46.6 \\
44.4\end{array}$ & $\begin{array}{l}7.4 \\
2.2 \\
5.0 \\
5.1 \\
6.5\end{array}$ & $\begin{array}{l}0.1 \\
0.1 \\
0.1 \\
0.6 \\
1.3\end{array}$ & $\begin{array}{l}\mathrm{HC} \\
\mathrm{HC} \\
\mathrm{SiC} \\
\mathrm{HC} \\
\mathrm{HC}\end{array}$ & $\begin{array}{c}18.5 \\
5.9 \\
14.7 \\
32.2 \\
29.3\end{array}$ \\
\hline
\end{tabular}

" Abbreviations: CL, clay loam; HC, heavy clay; LiC, light clay; SC, sandy clay; SCL, sandy clay loam; $\mathrm{SiC}$, silty clay. 
Table 3. Particle-size distribution averaged for alluvial soils of the respective agro-ecological regions in Vietnam.

\begin{tabular}{lrrrr}
\hline Agro-ecological region & Mean & S.D. & Min. & Max. \\
\hline 1. Red River Delta & & & & \\
- Clay content & 36.7 & 11.5 & 15.8 & 56.7 \\
- Silt content & 38.4 & 11.2 & 13.6 & 54.1 \\
- Fine sand content & 24.4 & 17.9 & 4.5 & 66.6 \\
- Coarse sand content & 0.5 & 0.8 & 0.1 & 3.5 \\
\hline 2. North of Central & & & & \\
- Clay content & 47.0 & 8.1 & 33.2 & 62.6 \\
- Silt content & 41.8 & 7.4 & 25.0 & 54.4 \\
- Fine sand content & 10.7 & 7.9 & 3.4 & 29.3 \\
- Coarse sand content & 0.5 & 0.4 & 0.1 & 1.4 \\
\hline 3. Coastal Area of Southern Central & & & & \\
- Clay content & 35.3 & 10.0 & 19.8 & 50.6 \\
- Silt content & 27.6 & 8.8 & 17.4 & 38.7 \\
- Fine sand content & 33.3 & 18.9 & 10.2 & 56.8 \\
- Coarse sand content & 3.7 & 1.9 & 0.5 & 6.4 \\
\hline 4. East of the South & & & & \\
- Clay content & 52.3 & 10.1 & 41.0 & 62.0 \\
- Silt content & 26.1 & 3.3 & 22.7 & 29.2 \\
- Fine sand content & 20.4 & 11.0 & 14.1 & 28.1 \\
- Coarse sand content & 1.2 & 1.2 & 0.1 & 2.3 \\
\hline 5. West of the South & & & & \\
- Clay content & 51.5 & 6.2 & 37.6 & 59.2 \\
- Silt content & 42.7 & 5.6 & 35.5 & 57.3 \\
- Fine sand content & 5.0 & 2.6 & 1.7 & 8.2 \\
- Coarse sand content & 0.7 & 0.9 & 0.1 & 2.4 \\
\hline All samples & & & & \\
- Clay content & 42.0 & 11.8 & 15.8 & 62.6 \\
- Silt content & 37.9 & 10.4 & 13.6 & 57.3 \\
- Fine sand content & 19.1 & 15.1 & 1.7 & 66.6 \\
- Coarse sand content & 0.9 & 1.4 & 0.1 & 6.4 \\
\hline
\end{tabular}

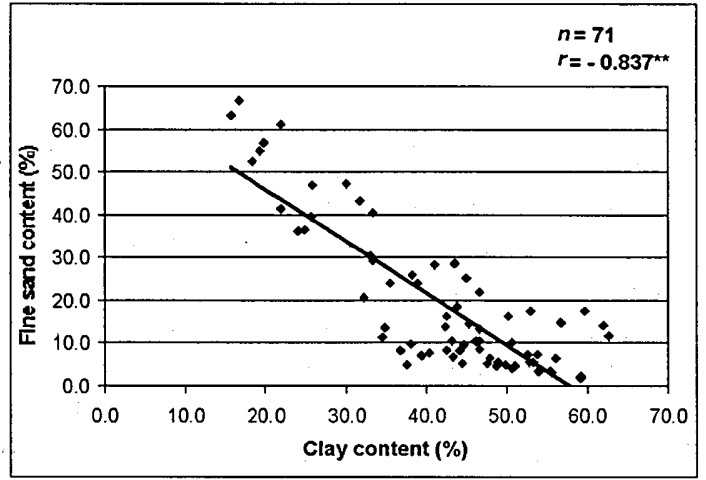

Fig. 2. Correlation between the clay and fine sand contents of alluvial soils in Vietnam. 


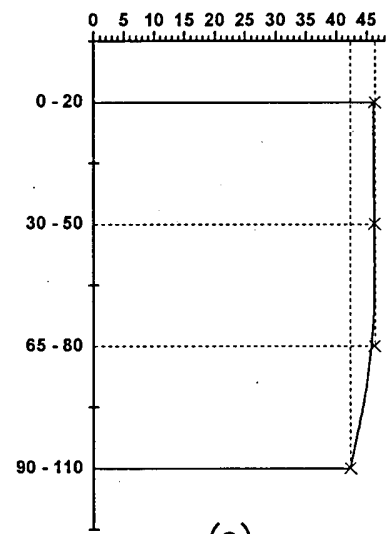

(a)

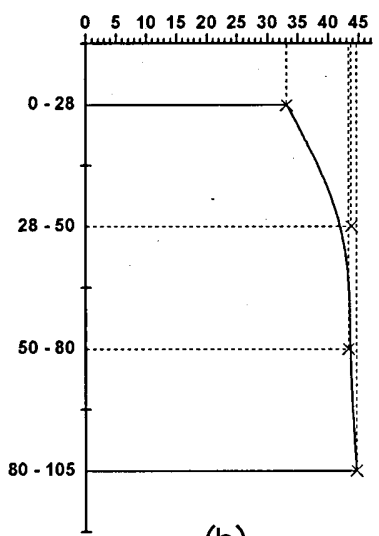

(b)

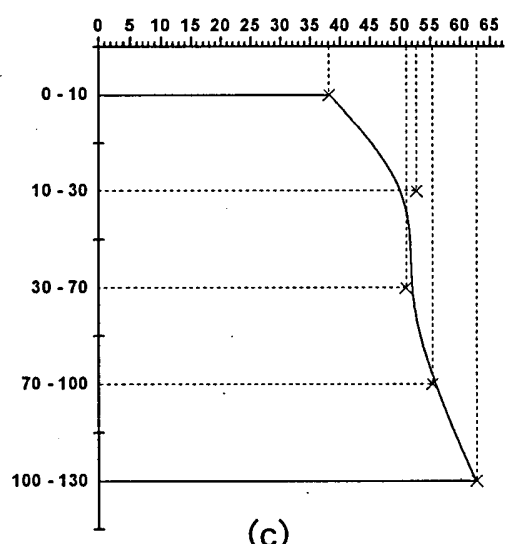

(c)

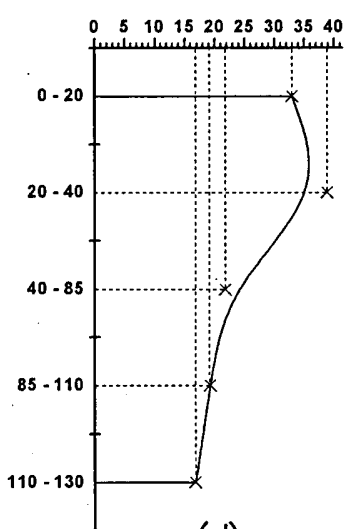

(d)

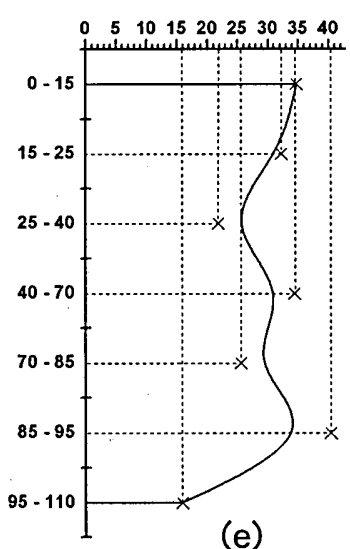

(e)

Fig. 3. Vertical distribution patterns of the clay content in a profile for profiles of (a) RD4, (b) LM1, (c) MA1, (d) TB1 and (e) RD2 as representing each of the five patterns.

the clay content throughout the profile (profiles RD3, RD4 and TB2), in which the contents of all particle fractions were fixed or in a narrow range. The lower clay content at surface with the constant content throughout the subsurface horizons in the pattern (b) (profiles RD5, LM1 and LM2) corresponds with the coarser texture at surface and the finer texture in lower horizons. Profiles MA1, TK1, BA1, DN1 and MK1 showed the gradual increase of the clay content with depth (pattern (c)). The lower clay content at surface or in the upper horizons belonging to the patterns (b) and (c) would be related to the loss of clay particles due to leaching, erosion and/or decomposition at different levels (Do. et al., 2002). Because of the situation near sea, profiles TB1, MK2 and MK3 were derived from a mixture of river and marine sediments. The overlay of river sediments on 
marine sediments resulted in a gradual decrease of the clay content with depth in these profiles and showed the vertical distribution of the pattern (d). The pattern (e), in which the clay content was distributed irregularly with depth, might be derived from breaks of the dike in the past. Strong floods cyclically broke the dike of the Red.River and transported the coarse sediments to the field. It made that alluvial soils adjacent to the river had an abrupt textural change as observed in profiles RD1 and RD2.

Alluvial soils of the North of Central, the Coastal Area of Southern Central, and the East of the South regions, where drainage basins of the rivers are small, had the same vertical distribution pattern of the clay content, pattern (c), except for alluvial soils of the Lam River system. In the West of the South region, two vertical distribution patterns of the patterns (c) and (d) were found, whereas all distribution patterns were observed in the Red River Delta region, except for the pattern (c), showing the profound and complex changes of alluvial soils in this agro-ecological region.

\section{Free iron oxides content}

Table 2 shows free iron oxides contents of all samples and Table 4 shows those averaged for samples of the respective agro-ecological regions and river systems. The variability in the free iron oxides content of alluvial soils was very large within river systems. For example, the free iron oxides content varied from 15.2 to $41.8 \mathrm{~g} / \mathrm{kg}$ for alluvial soils of the Red River system and from 5.9 to $46.2 \mathrm{~g} / \mathrm{kg}$ for those of the Mekong River system. The average of the free iron oxides content of alluvial soils from the Red River system $(25.2 \mathrm{~g} / \mathrm{kg})$ and the Thaibinh River system $(30.9 \mathrm{~g} / \mathrm{kg})$, representative for the Red River Delta region, was relatively low and comparable with that from the Mekong River system $(30.9 \mathrm{~g} / \mathrm{kg})$, representative for the West of the South region. For alluvial soils distributed in the small drainage basins such as the Ma River, Lam River, Trakhuc River and Dongnai River systems, the average of the free iron oxides content was mostly over $40 \mathrm{~g} / \mathrm{kg}$ and especially high for those from the Dongnai River system $(76.9 \mathrm{~g} / \mathrm{kg})$.

Table 4. Free iron oxides contents $(\mathrm{g} / \mathrm{kg}$ ) averaged for alluvial soils of the respective agro-ecological regions and river systems in Vietnam.

\begin{tabular}{lrrrr}
\hline Agro-ecological region/River system & Mean & S.D. & Min. & Max. \\
\hline $\begin{array}{l}\text { 1. Red River Delta } \\
\quad \text { - Red River }\end{array}$ & & & & \\
$\quad$ - Thaibinh River & 25.2 & 8.1 & 15.2 & 41.8 \\
$\quad 30.9$ & 21.6 & 5.3 & 77.8 \\
\hline $\begin{array}{l}\text { 2. North of Central } \\
\quad \text { - Ma River }\end{array}$ & 49.4 & 10.3 & 31.3 & 55.7 \\
$\quad$ - Lam River & 46.0 & 20.6 & 19.6 & 82.0 \\
\hline 3. Coastal Area of Southern Central & & & & \\
$\quad$ - Trakhuc River & 40.3 & 12.3 & 26.1 & 47.5 \\
$\quad$ - Ba River & 18.9 & 4.7 & 13.1 & 24.3 \\
\hline 4. East of the South & & & & \\
$\quad$ - Dongnai River & 76.9 & 4.8 & 74.0 & 84.1 \\
\hline 5. West of the South & & & & \\
$\quad$ - Mekong River & 30.9 & 12.3 & 5.9 & 46.2 \\
\hline All samples & 34.1 & 18.5 & 5.3 & 84.1 \\
\hline
\end{tabular}




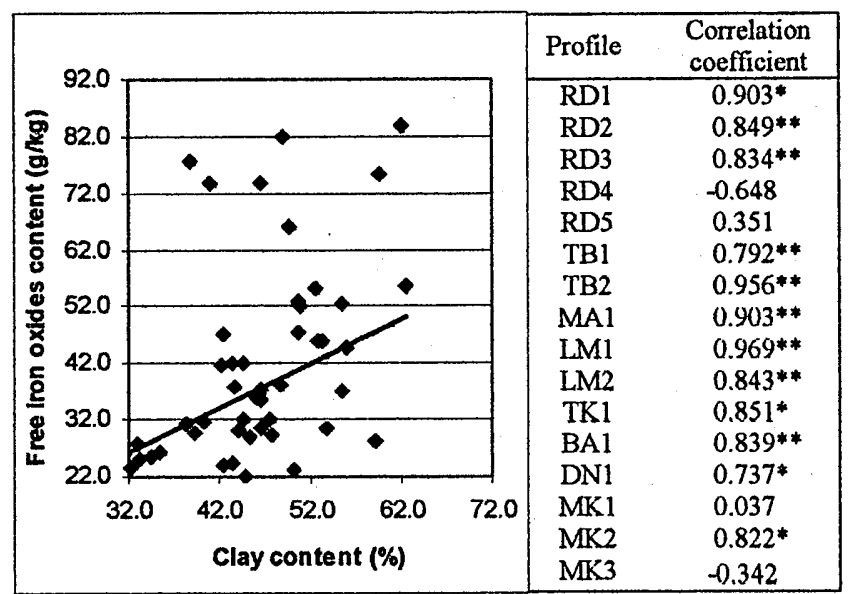

Fig. 4. Illustration of the linear relationship between the free iron oxides and clay contents in a profile, and correlation coefficients for individual soil profile of alluvial soils in Vietnam.

The variability in the free iron oxides content among the river systems can be attributed to the differences in the sediment sources. The researches on Chinese soils (Dai et al., 2003; Xu et al., 2003) and Brazilian soils (Antonio et al., 2003) showed that the free iron oxides content of upland soils (Oxisols, Alfisols and Ultisols) were much higher than those of lowland soils (Luvisols, Vertisols and Inceptisols). The drainage basins of river systems distributed in the North of Central, the Coastal Area of Southern Central and the East of the South regions are very small and surrounded by upland soils. Runoff water transports weathering materials from surrounding areas to the basin and mixes them with river sediments. Because of such formation process, alluvial soils from those river systems had the high free iron oxides contents in comparison with those in the Red River Delta and the West of the South regions. The coarse texture would be concerned with the lowest value of the free iron oxides content observed for alluvial soils from the $\mathrm{Ba}$ River system $(18.9 \mathrm{~g} / \mathrm{kg})$.

In general, the free iron oxides and clay contents in a profile had a significant linear relationship with correlation coefficients more than 0.7 (Fig. 4): when the clay content increases the free iron oxides content also increases. In some cases, however, the vertical distribution of the free iron oxides content was controlled by soil formation process. In this context, profiles RD4 and RD5 are Gleyic Fluvisols developed on the area where soils are completely saturated with groundwater at least for a period of the year that allows occurrence of the reducing condition. Under that condition, ferric compounds were transformed into ferrous compounds, which are more soluble and easily transported to lower horizons with percolating water. This process would result in the vertical distribution of the free iron oxides content which did not parallel with that of the clay content. The associated distribution of alluvial soils with acid sulfate soils (Thionic Fluvisols) in the West of the South region would result in transportation of pyrite $\left(\mathrm{FeS}_{2}\right)$ 
to alluvial soils. As a result, the vertical distribution of the free iron oxides content did not parallel with the clay content in profiles MK1 and MK3, showing insignificant correlation coefficients between them. Profile MK2 in the same agro-ecological region as profiles MK1 and MK3 but situated apart from acid sulfate soils, had a significant correlation coefficient between the free iron oxides and clay contents.

In addition, the vertical distribution of the free iron oxides in a profile was controlled by land management. The research by Egashira et al. (2002) on grey degraded soils in Vietnam showed the distribution pattern of free iron oxides of the lower contents in the upper horizons and the higher contents in the lower horizons, and they attributed it to the vertical movement of free iron oxides due to alternation of the reduction and oxidation processes in soils subjected to the long-time cultivation of paddy rice. Under the waterlogged condition, ferric compounds are reduced to ferrous compounds in upper horizons and then reoxidized to ferric compounds after transportation to lower horizons where the oxidized condition is prevailing. They tentatively proposed continuation of the chemical processes caused by alternative reduction and oxidation as a mechanism of the formation of grey degraded soils in Vietnam. In the present study, all samples are alluvial soils subjected to intensive paddy rice cultivation and many of them showed the lower contents of free iron oxides in upper horizons. It is plausible that there is occurrence of the same chemical processes by alternative reduction and oxidation in alluvial soils as in grey degraded soils. If this is the case, some alluvial soils in Vietnam have been degraded. Other evidences for degradation of alluvial soils are occurrence of reddish yellow subsurface horizons and the clay loss in upper horizons of some alluvial soils.

Concerning the mechanism of the formation of grey degraded soils, Do et al. (2002) have pointed out that the main cause for the clay loss in upper horizons is decomposition and dissolution of layer silicate (halloysite) and iron oxide (goethite) minerals. The proof is that halloysite and goethite are absent or exist with small amounts in upper horizons but occur with large amounts in lower horizons. As mentioned in the part of Particles-size distribution, many profiles manifested the clay loss at surface or in upper horizons. It was shown in profiles RD5, LM1 and LM2, and more distinct in profiles MA1, TK1, BA1, DN1 and MK1. To find out whether the main cause for the clay loss in alluvial soils is the same as that in grey degraded soils, analysis of clay mineralogy of alluvial soils is needed.

\section{CONCLUSIONS}

Alluvial soils from different agro-ecological regions/river systems in Vietnam had different particle-size distributions and free iron oxides contents due to differences in the sediment sources. Within a profile, the vertical distribution pattern of the clay and free iron oxides contents was found to be controlled by soil forming processes and/or land management. In most profiles, the free iron oxides content showed a significant and positive relationship with the clay content. Many samples of alluvial soils showed the clay loss and the lower content of free iron oxides in upper horizons; this feature was the same as that observed in grey degraded soils but at the lower level. This leaded to the supposition that some alluvial soils in Vietnam have been degraded. However, it should be verified in the future study through clay mineralogical analysis. 


\section{ACKNOWLEDGEMENTS}

We would like to express our sincere thanks to managers of the projects: Surveying and Evaluating Soil Quality to Establish Soil Reference, Database and Information in Vietnam; and Study in Establishing the Data Guidelines on Environmental Quality of Vietnam Fluvisols for providing soil samples and related documents, and to Dr. Ho Quang Duc and Mr. Nguyen Van Ty, Department of Soil Genesis and Classification Research, and to Dr. Pham Quang Ha, Department of Soil Environment Research, National Institute for Soils and Fertilizers, Ministry of Agriculture and Rural Development, Vietnam, for their assistance in collecting soil samples.

\section{REFERENCES}

Antonio, C. S. C., M. B. Jerry, A. T. Cássio and C. P. José 2003 Clay mineralogy and cation exchange capacity of Brazilian soils from water contents determined by thermal analysis. Thermochimica Acta, 413: 73-79

Asamoa, G. K. 1973 Particle-size and free iron oxide distribution in some Latosols and groundwater laterites of Ghana. Geoderma, 10: 285-297

Dai, J. L., M. Zhang and Y. G. Zhu 2003 Adsorption and desorption of iodine by various Chinese soils. Environment Intermational, 30: 525-530

Do, N. H., Q. H. Trinh and K. Egashira 2002 Mineralogy and clay degradation in grey degraded soils of Vietnam. Clay Science, 11: 535-547

Egashira, K., A. Kaieda and N. H. Do 2002 General chemical fertility and chemical processes of grey degraded soils as a problem soils in Vietnam. Journal of the Faculty of Agriculture, Kyushu University, 47: 437-445

Hillel, D. 1980 Fundamentals of Soil Physics. Academic Press, New York

National Institute for Soils and Fertilizers (NISF) and Department of Science, Technology and Product Quality (DSTPQ), Ministry of Agriculture and Rural Development (MARD) 2002 The Basic Information of Main Soil Units of Vietnam. Thegioi Publishers, Hanoi, Vietnam

Nguyen, H. T. and K. Egashira 2000 Clay mineralogical composition of some Fluvisols in Vietnam. Clay Science, 11: 205-217

$\mathrm{Xu}, \mathrm{R}$., A. Zhao and G. Ji 2003 Effect of low-molecular-weight organic anions on surface charge of variable charge soils. Journal of Colloid and Interface Science, 264: 322-326

Yong, R. N. and B. P. Warkentin 1975 Soil Properties and Behaviours. Elsevier Scientific Publishing Company, Amsterdam, The Nerherlands 